\title{
Anhydrite and gypsum in the Devonian and Permian evaporite lithofacies of Belarus: a review
}

\author{
Anatoliy MAKHNACH ${ }^{1, *}$, Vladimir SHIMANOVICH ${ }^{1}$, Galina STRELTSOVA ${ }^{1}$ \\ and Nikolay MIKHAYLOV ${ }^{1}$ \\ 1 Research and Production Centre for Geology, Academician Kuprevich 7, 220141 Minsk, Belarus
}

Makhnach, A., Shimanovich, V., Streltsova, G., Mikhaylov, N., 2014. Anhydrite and gypsum in the Devonian and Permian evaporite lithofacies of Belarus: a review. Geological Quarterly, 58 (3): 577-590, doi: 10.7306/gq.1165

\begin{abstract}
Anhydrite is widespread in the Prypiać Trough in the form of beds and nodules in the Subsaliferous Terrigenous and Carbonate formations (Eifelian and Frasnian), the Lower Saliferous Formation (Frasnian), the Intersaliferous and Upper Saliferous formations (Famennian). It is also present in the Asselian and Sakmarian (Lower Permian) deposits of the trough. The anhydrite is grey, blue, pink and orange. It has massive and, more rarely, horizontal bedding, and a fine- and micro-crystalline structure. Gypsum extends widely across the Orša Depression, Žlobin and Latvijas Saddles and partly in the Belarusian Anteclise, where it lies within the Eifelian deposits. It is also found in the Frasnian strata of the North-Prypiać Shoulder. As a component of facial analogue of the Upper Saliferous Formation gypsum forms the Bryniou deposit in the west of the Prypiać Trough. This mineral is also observed in the Oversaliferous Formation (Famennian) and in the Asselian and Sakmarian strata of the trough. There are spar, saccharoidal, alabastrine and selenitic varieties of gypsum. A medium to coarse crystalline structure is typical. The gypsum is grey, pink, yellow or orange.
\end{abstract}

Key words: anhydrite, gypsum, evaporites, Devonian, Permian, Belarus.

\section{INTRODUCTION}

In spite of the wide distribution of anhydrite and gypsum in Belarus much less attention was traditionally given to their study than to investigation of carbonate, terrigenous and salt rocks. Within this, anhydrite and gypsum in evaporite lithofacies where they occur mainly as individual beds and units, are studied less than those in non-evaporite lithofaces where they are not rock-forming minerals but fill pores, cavities and fissures in carbonate and terrigenous rocks. Beds of calcium sulphate are useful indicators of salinity levels in a sedimentary basin, and the bedded anhydrite-gypsum transition is evidence of near-surface transformation of sedimentary successions and of the depositional conditions of gypsum. These two aspects, considered important for palaeogeographic and palaeotectonic reconstructions and mineral resources prospecting, show the relevance of the study of anhydrite and gypsum within evaporite lithofacies.

This paper summarizes data on the occurrence, textures, structures and genetic features of anhydrite and gypsum strata, beds and nodules across Belarus. Evaporite lithofacies com-

\footnotetext{
* Corresponding author: amahnach@geology.org.by
}

Received: April 16, 2013; accepted: March 21, 2014; first published online: April 17, 2014 prising anhydrite and/or gypsum occur in many stratigraphic units of the Devonian and Permian (Tables 1 and 2) within several tectonic units within Belarus (Figs. 1 and 2).

\section{ANHYDRITE}

\section{MIDDLE AND UPPER DEVONIAN}

\section{SUBSALIFEROUS TERRIGENOUS} AND CARBONATE FORMATIONS

Anhydrite is widespread in evaporite lithofacies of the Subsaliferous Terrigenous and Carbonate formations of the Prypiać Trough. It is confined to the Eifelian and Frasnian strata.

Eifelian. Anhydrite occurs in the form of thin (up to $2 \mathrm{~m}$ ) interlayers and nodules in dolomites, marls, sandstones and clays of the Asvieja Unit which belongs to the Subsaliferous Terrigenous Formation (Table 1; Figs. 2 and $3 \mathrm{~A}$ ). The thickness of the unit is up to $40 \mathrm{~m}$ (Makhnach et al., 1966; Kurochka, 1968; Pozniakevich, 1974; Uriev and Anpilogov, 1977). The anhydrite is grey, blue, pink and orange. It is massive and, more rarely, horizontally bedded with a fine- and microcrystalline structure (Fig. 3B). Compound rocks comprising anhydrite are usual in the Asvieja Unit. The components of these rocks show a variety of structural and lithological relationships. 
$\mathrm{Tab}$ e 1

The Devonian stratigraphic units of the Prypiać Trough containing sulphate minerals (bold letters) in evaporite lithofacies (Kruchek et al., 2010)

\begin{tabular}{|c|c|c|c|}
\hline System & Stage & $\begin{array}{c}\text { SUPERUNIT } \\
\text { or unit }\end{array}$ & Formation \\
\hline \multirow{23}{*}{ Devonian } & \multirow{9}{*}{ Famennian } & Kalinaŭka & \multirow{2}{*}{ Oversaliferous } \\
\hline & & PALIESSIE & \\
\hline & & Strešyn & \multirow{3}{*}{ Upper Saliferous } \\
\hline & & Aresa & \\
\hline & & Lebedyan & \\
\hline & & Pietrykaŭ & \multirow{4}{*}{ Intersaliferous } \\
\hline & & ELETS & \\
\hline & & ZADONSK & \\
\hline & & Damanavičy & \\
\hline & \multirow{7}{*}{ Frasnian } & Černin & Lower Saliferous \\
\hline & & EVLANOVO & \multirow{5}{*}{$\begin{array}{c}\text { Subsaliferous } \\
\text { Carbonate }\end{array}$} \\
\hline & & Voronezh & \\
\hline & & Rečyca & \\
\hline & & Semiluki & \\
\hline & & Sargaevo & \\
\hline & & Žaloń & \multirow{8}{*}{$\begin{array}{c}\text { Subsaliferous } \\
\text { Terrigenous }\end{array}$} \\
\hline & \multirow{2}{*}{ Givetian } & Ubarć & \\
\hline & & Polack & \\
\hline & \multirow{4}{*}{ Eifelian } & Kasciukovičy & \\
\hline & & Haradok & \\
\hline & & Asvieja & \\
\hline & & Adroŭ & \\
\hline & Emsian & Viciebsk & \\
\hline
\end{tabular}

$\mathrm{Table} 2$ The Permian stratigraphic units of the Prypiać Trough
containing sulphate minerals (bold letters) in evaporite lithofacies (Kruchek et al., 2010)

\begin{tabular}{|c|c|c|c|}
\hline System & Stage & Suite & Subsuite \\
\hline \multirow{8}{*}{ Permian } & Viatkian & \multirow{2}{*}{ Dudzičy } & Upper \\
\hline & Severodvinian & & Lower \\
\hline & \multirow{4}{*}{ Sakmarian } & Pre-Dudzičy & \\
\hline & & \multirow{3}{*}{ Svaboda } & Upper (salinizated) \\
\hline & & & $\begin{array}{c}\text { Middle } \\
\text { (terrigenous) }\end{array}$ \\
\hline & & & Lower (saliferous) \\
\hline & \multirow{2}{*}{ Asselian } & \multirow{2}{*}{ Prudok } & $\begin{array}{c}\text { Upper } \\
\text { (sulphate-bearing) }\end{array}$ \\
\hline & & & $\begin{array}{c}\text { Lower } \\
\text { (sulphate-lacking) }\end{array}$ \\
\hline
\end{tabular}

Deposits of the Asvieja Unit in the Prypiać Trough are rather poorly studied because they are deeply buried across most of the trough, with oil prospecting work large occurring above. The Asvieja anhydrite, which appears to be the oldest evaporite formation in Belarus, extends throughout the Prypiać Trough. Gypsum together with anhydrite occurs in marginal zones of the trough where the Asvieja deposits are shallowly located (Fig. 1).
An anhydrite bed (4-7-m-thick) containing inclusions and lenticular interlayers of carbonate and clay material is located in salt-bearing sections of the Asvieja Unit (the Marmaryčy, Viša and Karma local structures - see Fig. 2) and overlies the rock salt. The main mass of anhydrite is characterized by clear lamination and thin rhythmicity; the laminar fabric of anhydrite-bearing rocks is indistinct and lenticular near the contact with the rock salt, some interlayers being disturbed or broken. The structure of pure varieties of anhydrite is matted-fibrous and lamellar. Anhydrite is incorporated into rock salt beds together with clay and carbonate. It forms thin interlayers and individual inclusions among halite grains. There are also blastic anhydrite fringes on clay inclusions. In this case anhydrite consists of very fine crystals of elongate-columnar and needle-like shape. This is evidence of the primary origin of anhydrite which was precipitated directly from evaporate brines and did not replace gypsum (Yarzhemskiy, 1960).

Frasnian. Two types of anhydrite are distinguished in the Frasnian deposits of the Subsaliferous Terrigenous and Subsaliferous Carbonate formations. These are: (a) beds and interlayers, the depositional origin of which is obvious and (b) nodules within in non-evaporite rocks (mudstones, dolomites, sandstones).

Anhydrite beds revealed in the Žaloń Unit, Evlanovo Superunit, Sargaevo and Voronezh units (Makhnach et al., 1966; Uriev and Anpilogov, 1977) show a seemingly lithological uniformity of sulphate rocks (usually, massive texture and microcrystalline structure; the latter is easily visible under high magnification; Fig. 4). Detailed lithological, mineralogical and geochemical investigations may contribute to understanding the Prypiać Basin geological history. For example, the wide range of the $\delta^{34} S$ values in anhydrite $(+18.1$ to $+35.6 \%$ indicates significant variability of conditions of calcium sulphate precipitation (Makhnach et al., 2000; Peryt et al., 2007). Lower $\delta^{34} \mathrm{~S}$ values are a signal of an isotopically light sulphate supply to the evaporite basin with new sea water supply, while higher values are the result of intensive biogenic sulphate reduction. Therefore, it is possible to obtain significant palaeogeographical information by studying sulphur isotopes and other characteristics of anhydrite within a regionally extensive stratigraphical level.

The Žaloń Unit contains thin (up to $15 \mathrm{~cm}$ ) anhydrite interlayers. A geological unit comprising anhydrite together with carbonate is recognized in the lower part of the Sargaevo Unit; individual anhydrite interlayers at the top of the unit are observed in the south of the trough. Similar interlayers are distinguished in the Voronezh Unit within the western part of the Prypiać Basin. The frequent presence of anhydrite beds and significant sulphate admixture in clay and carbonate rocks are characteristic features of the Evlanovo Superunit.

We now provide examples of the anhydrite nodule occurrences in the Frasnian deposits (Fig. 5). Nodules of anhydrite are frequent in the Žalon Unit. For instance, anhydrite tablets and lenses occur in tabular greenish-grey argillite within the Jeĺsk structure (borehole 38, depth 4830-4836 m). These are 2 to $3 \mathrm{~cm}$ across, the colour of the anhydrite being pink. Borehole 1 within the Hostaŭ structure revealed green massive argillite with bright pink ellipsoidal bodies (2-2.5 $\mathrm{cm}$ across) at the depth interval of 3784-3807 m. The bodies consist of tangled-lamellar anhydrite and are clearly detached from the host rock. They are often elongated parallel to bedding. Similar nodules are found in greenish-grey quartzose sandstone (depth $3681 \mathrm{~m}$ ) and speckled argillite (3668-3674 m) within the South-Voziemlia structure (borehole 1). 


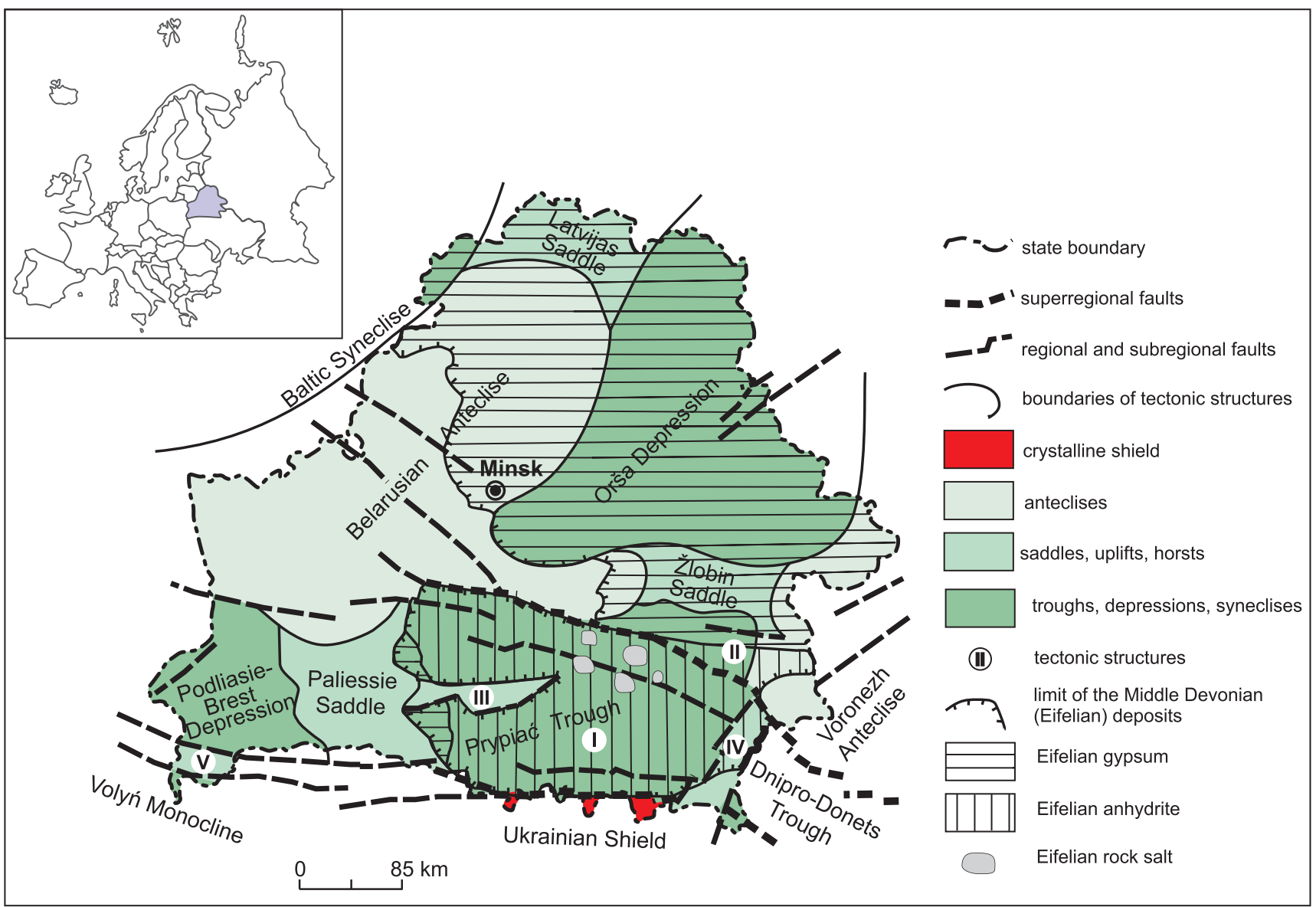

Fig. 1. The main tectonic structures and occurrence of the Middle Devonian (Eifelian) evaporites within Belarus (Makhnach et al., 2001)

I - Prypiać Graben, II - North-Prypiać Shoulder, III - Mikaševičy-Žytkavičy Uplift, IV - Brahin-Loeŭ Saddle, V - Lukiv-Ratne Horst

White fine-grained anhydrite composes a nodule of $4 \mathrm{~cm}$ across within dark grey massive dolomite of the Rečyca Unit in the Sudavica structure (borehole 8, depth $4528-4540 \mathrm{~m}$ ). Black homogeneous argillite of this horizon contains pink anhydrite nodules $(0.2-1.3 \mathrm{~cm})$ within the Makanavičy structure (borehole 2, depth 3535-3543 m).

Anhydrite nodules are common in carbonate and argillaceous carbonate rocks of the Voronezh Unit. Nodules are light grey, bluish-grey or pinkish-grey and up to $6 \mathrm{~cm}$ across. Locally, nodules are elongated parallel to bedding. These bodies were found within the Sudavica (borehole 8, depth 4510-4520 m), Makanavičy (borehole 2, 3478-3484 m), Navasiolki (borehole 1, 4276-4277 and 4329-4349 m), South-Voziemlia (borehole 1, 3572-3585 m) and other structures.

Nodules formed at an early diagenetic stage in non-lithified sediments as indicated by their shape, small size of anhydrite crystals, compact packing in the host rock, frequent occurrence in impermeable deposits in which mass transfer is scarcely possible after lithification. Apart from anhydrite nodules which are scattered in the non-sulphate rocks described above, there are aggregations of nodules forming entire layers and seams of mosaic (nodular) anhydrite rock where carbon- ate or argillaceous substrate comprises thin inter-nodule films only. Belarusian lithologists designate such rocks as anhydrite with a "stone masonry" texture. It is very likely that anhydrite nodules and mosaic anhydrites are products of the same secondary processes taking place at different intensities.

Two mechanisms of anhydrite nodule formation are possible:

- Firstly, concretionary diagenetic origin of the nodules is not ruled out. Such mechanism is supported by experimental simulation of sulphate nodule formation under conditions of semiliquid sediment flow (Riley and Byrne, 1961) and by the fact that nodules commonly occur in those units of the trough sequence where there are also bedded anhydrites.

- Secondly, there is a reason to connect nodule formation with a sabkha environment. Their nodular shape is typical to such conditions. The sabkha model of nodule formation is the most appropriate for the deposits that accumulated at the rift stage of the Prypiać Trough evolution (the Rečyca and younger units), when there was considerable bathymetric differentiation of the basin and periodically flooded islands existed. 


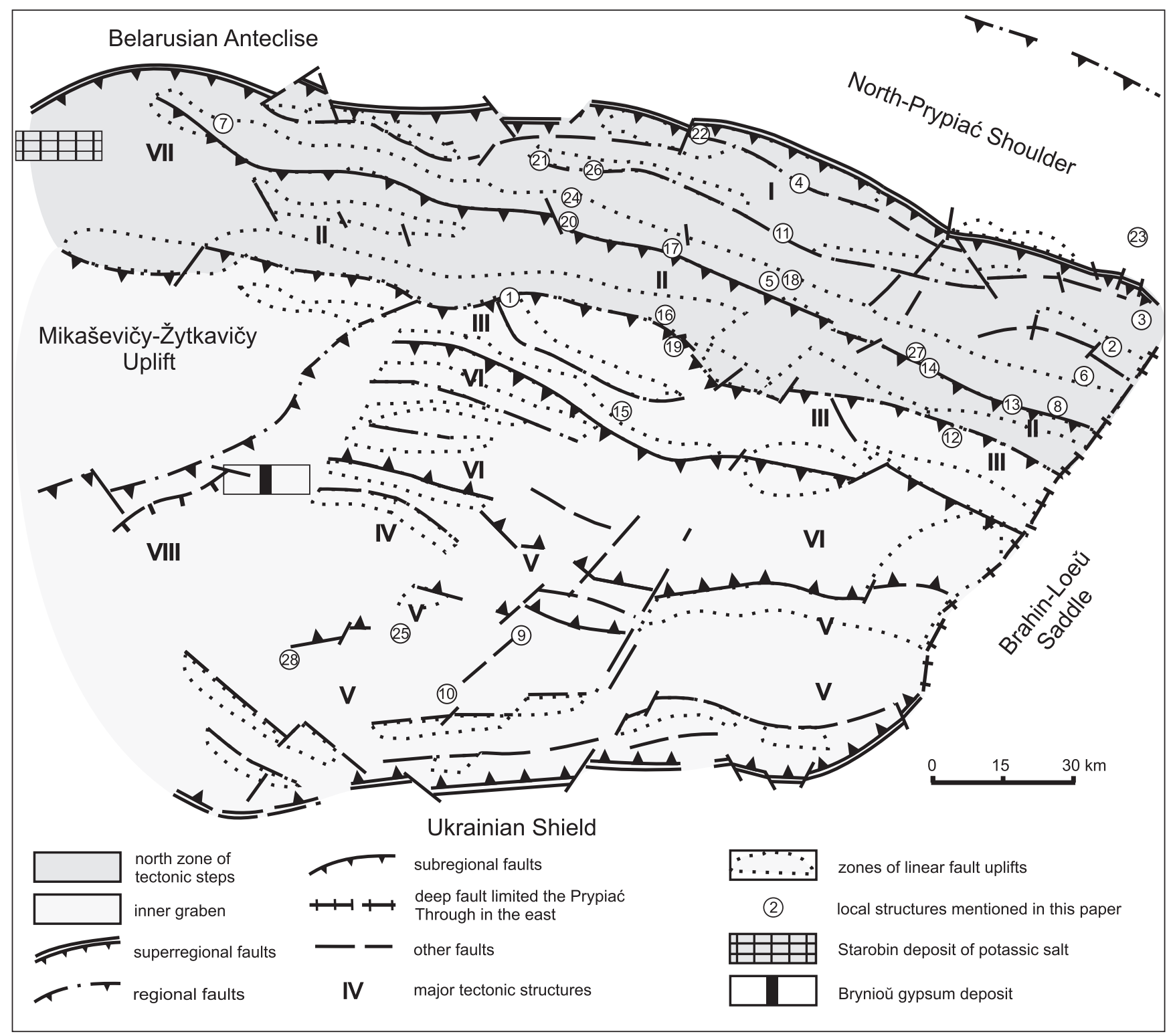

Fig. 2. The tectonic scheme of the Prypiać Trough (Makhnach et al., 2001)

Major structures: I - Rečyca-Šacilki step, II - Čyrvonaja Slabada-Maladuša step, III - Zarečča-Vialiki Bor step, IV - Šastovičy-Skalodzin step, V - Naroŭlia-Jeĺsk step, VI - Pietrykaŭ-Chojniki zone of axial buried uplifts and periclines, VII - Starobin centriclinal depression, VIII Turaŭ centriclinal depression; local structures: 1 - Akciabrski, 2 - Aliaksandraŭka, 3 -Barščoŭka, 4 - Biarezina, 5 - Davydaŭka, 6 - Dniapro, 7 - Drazdoŭka, 8 - East-Siamionaŭka, 9 - Hostaŭ, 10 - Jeĺsk, 11 - Karma, 12 - Makanavičy, 13 - Maladuša, 14 - Marmaryčy, 15 Navasiolki, 16 - North-Damanavičy, 17 - Paliessie, 18 - Sasnoǔka, 19 - South-Damanavičy, 20 - South-Viša, 21 - South-Voziemlia, 22 Sudavica, 23 - Uvaravičy, 24 - Viša, 25 - West-Buda-Safijeŭka, 26 - West-Černin, 27 - West-Ciškaŭka, 28 - West-Dubraŭka

\section{UPPER DEVONIAN}

LOWER SALIFEROUS FORMATION

Anhydrite is widespread in the Lower Saliferous Formation of the Prypiać Trough. It occurs in salt-bearing units throughout the trough and in non-salt facies analogue of those in the west of the basin and also within the North-Prypiać Shoulder (Fig. 2).
It is seen in all eight rhythmic units of the formation comprising separate interlayers and beds of different thickness, monogene aggregates and inclusions of various shapes. However, the most widespread form of anhydrite is as impurities in mixed anhydrite-clay-carbonate seams. Also, it usually can be found in rock salt in the form of scattered impurities.

The Lower Saliferous Formation does not contain rock salt in the northwestern margin of the Prypiać Trough (the Starobin 

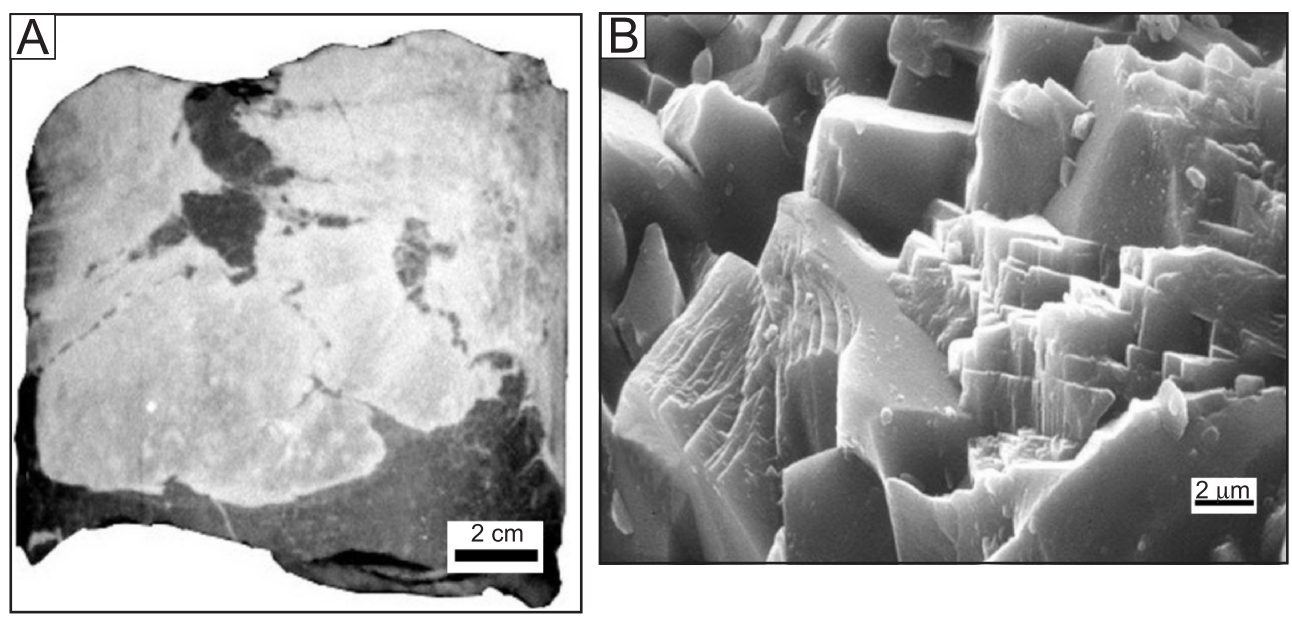

Fig. 3. Anhydrite in the Asvieja Unit of the Prypiać Trough; borehole East-Siamionaŭka 1 (depth 4003-4011 m)

A - nodular anhydrite (light) in argillite, core photograph; B - structure of anhydrite under SEM

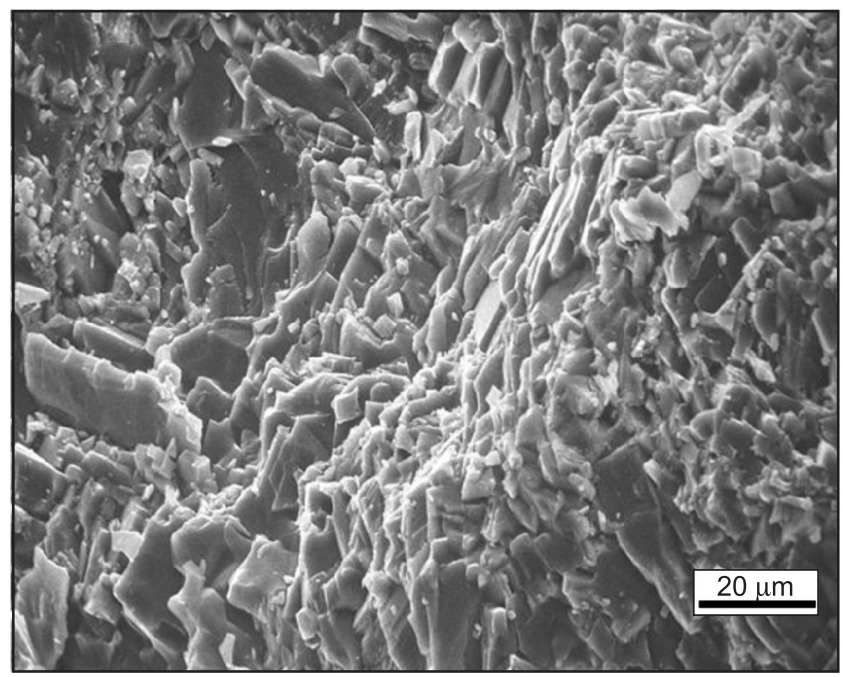

Fig. 4. The structure of bedded anhydrite in the Sargaevo Unit of the Prypiać Trough; borehole West-Černin 6 (depth 3774-3778 m)

Electron microscope photo

centriclinal depression). There, the formation includes carbonate, terrigenous and sulphate lithofacies (dolomites, marls and clays with anhydrite interlayers). Anhydrite together with prevailing terrigenous rocks and limestones also occurs in the southwestern part of the trough (the Turau centriclinal depression).

The mineral composition, structure, texture and habit of sulphate and sulphate-bearing rocks of the Lower Saliferous Formation are varied (Garetskiy et al., 1982). Massive, laminated, lenticular, nodular and spotted textures of anhydrite and anhydrite-bearing rocks are found. A laminated texture prevails, comprising thin horizontal alternations of clay, dolomite and anhydrite material. The structure of anhydrite in rocks with a laminated texture is fine-grained; carbonate interlayers contain separate small plates of anhydrite. The purest anhydrite, of massive texture, has a fine-grained and tangled-fibrous structure which alters to a mosaic or sheaf-like one upon recry- stallisation. Sulphate rocks with a lenticular and nodular texture comprise pure anhydrite aggregates of oval or rounded shape which are distributed in a carbonate-anhydrite or clay-carbonate matrix. The structure of this rock variety is tangled-fibrous and lamellar, fine-grained. Among the signs of recrystallisation in these rocks are segregations of medium-grained anhydrite in the form of prismatic and tabular crystals gathered into sheaf-like bundles or fantails. A spotted texture of anhydrite and anhydrite-bearing rocks is conditioned by the presence of carbonate and clay aggregations.

Anhydrite occurs within different rocks. It fills pores, fissures, caverns in carbonates, and forms cement in terrigenous rocks and tuffs. Lenses and aggregates of fine-grained tangled-fibrous anhydrite are present in dolomitic marls and carbonate clays; the content of anhydrite is up to $18 \%$ in these rocks.

Anhydrite forms tiny needle-shaped crystals associated with clay lumps and sheets in rock salt. Otherwise, it is found as a powder on the facets of halite crystals and as inclusions inside the crystals. This shows that anhydrite (not gypsum) was here a primary sedimentary mineral phase during the evaporative process. The reasons for this are probably low water activity in highly concentrated surface and near-bottom brines of chloride-calcium type, and high temperature.

The mineral composition of the water-insoluble residue of the Lower Saliferous Formation salt was studied in the samples from the Barščoŭka, Biarezina, Dniapro, Maladuša, Sasnoŭka and West-Buda-Safijeŭka structures (Fig. 2). Anhydrite appears to be a single sulphate in the accessory mineral associations of the salt in most cases. With that, it rarely comprises a significant part in the sulphate-pyrite-quartz-carbonate mineral association, as a rule being subordinate to carbonate and, more rarely to pyrite. Anhydrite forms separate lamellar crystals which in places grow together with carbonate grains (Fig. 6).

\section{INTERSALIFEROUS FORMATION}

The anhydrite beds occur at different stratigraphic levels of the Intersaliferous Formation of the Prypiać Trough. Predominantly, these beds lie within shallow shelf carbonate deposits. 


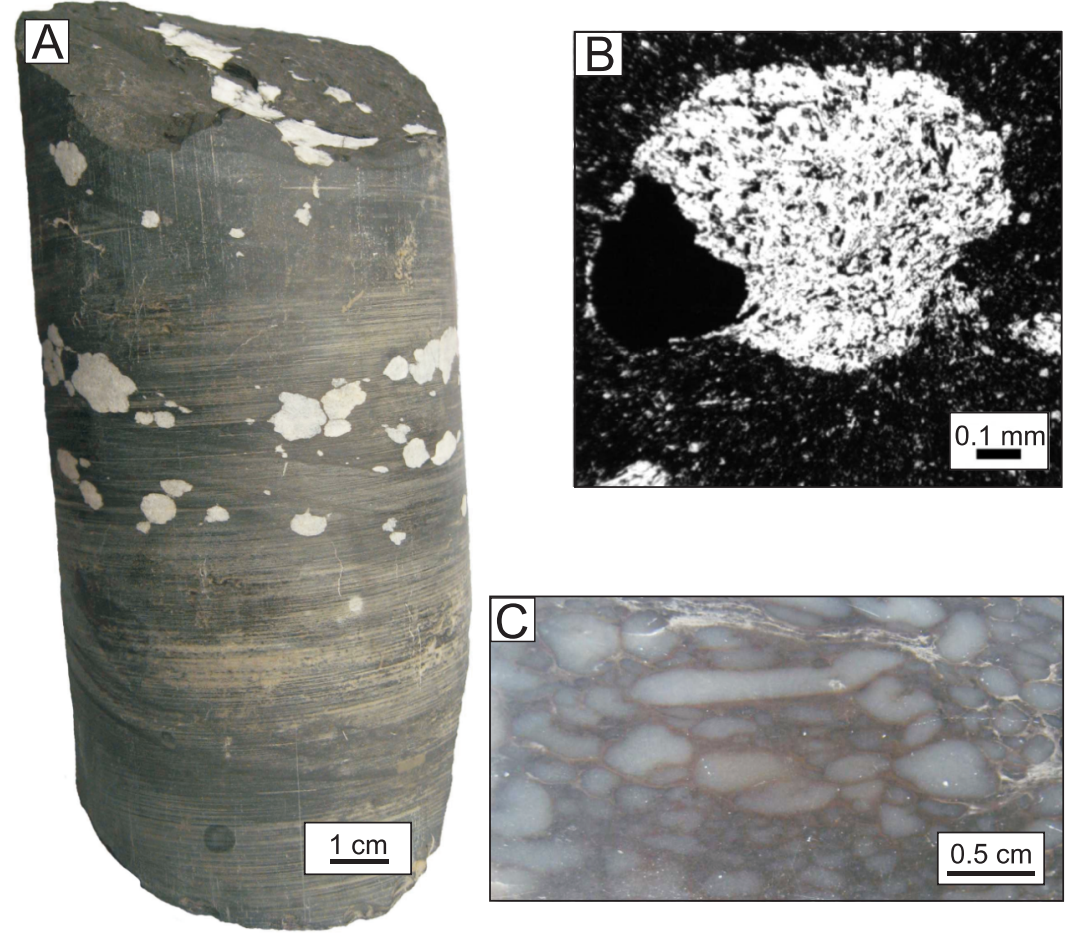

Fig. 5. Nodules of anhydrite in the subsaliferous deposits of the Prypiać Trough

A - a group of nodules in limestone, East-Siamionaŭka 1 borehole (depth 3693-3702 m) the Voronezh Unit, core photograph; B - anhydrite nodule with pyrite (black) in calcareous argillite, Hostaŭ 1 borehole (depth 3784-3801 m) the Žaloń Unit, plane-polarized photomicrograph; C - anhydrite with a "stone masonry" texture, Sasnoŭka 28 borehole (depth 3344-3372 m) the Evlanovo Superunit, core photograph

An anhydrite bed 0.5-15-m-thick on the border of the Lower and Upper Zadonsk deposits has a wide distribution, making up the regional benchmark «A» (Kruchek, 1979). Makhnach et al. (1979) described the distribution of anhydrite rocks in the sequence of the Intersaliferous Formation. These rocks make up to $6 \%$ of the Lower Zadonsk strata within the trough. The Upper Zadonsk deposits contain anhydrite rocks to a maximum of $13 \%$ in the Akciabrski, North-Damanavičy and Viša structures (Fig. 2). Sulphate rocks are absent in many sections of the Elets Supeunit; their maximum content is less than $2 \%$. Usually, the anhydrite texture is massive. Clayey varieties of anhydrite show a laminated texture. The structure of anhydrite rocks is finegrained and microcrystalline.

Anhydrite nodules in carbonate and clay-carbonate rocks are found in various stratigraphic units of the Intersaliferous Formation (e.g., the Sudavica structure, borehole 4, 3690-3712 m; borehole 8, 3769-3775 m) (Makhnach, 1989). They are probably diagenetic products similar to those in the subsaliferous strata described above. The nodules indicate high salinization of separate parts of the basin which, however, did not lead to formation of anhydrite beds.

\section{UPPER SALIFEROUS FORMATION}

Halite Subformation. The Halite Subformation of the Upper Saliferous Formation of the Prypiać Trough comprises the Lebedyan Unit (Table 1). Anhydrite comprises a significant part of it, composing many beds and interlayers, represented in do- lomite-sulphate and other mixed rocks, and forming macroinclusions and scattered impurities in rock salt.

Anhydrite rocks of the Halite Subformation, in contrast to sulphate rocks of other salt-bearing units of the trough, are especially pure. The content of $\mathrm{CaSO}_{4}$ in these anhydrite types is up to $100 \%$, and the content of impurities, mainly calcite, does not exceed $25 \%$. The colour of the anhydrite is various - from white and pearl-grey to dark grey and black. In texture the anhydrite is massive, laminated, spotted, lenticular or brecciated, the structure being finegrained, squamous or tangled-fibrous. Small bodies of medium-grained anhydrite of prismatic shape occur within recrystallised stretches. Prismatic anhydrite crystals fill fissures in non-salt rocks of different composition.

Peculiar carbonate-anhydrite deposits at the bottom of the Halite Subformation (the Baryčaŭ beds, after Kruchek, 1979) and similar deposits in overlying non-salt layers of the subformation (Moskvich and Konischev, 1986) are of special interest due to the presence of oil there. These deposits form the anhydrite swell developed along the Rečyca-Šacilki step (Fig. 2). The swell is tens of kilometres long and $2-3 \mathrm{~km}$ wide. The thickness of deposits within the swell changes from $113 \mathrm{~m}$ at the tops of highs to a total pinching-out on their flanks. Grey anhydrite contains thick (up to $50 \mathrm{~m}$ ) lenticular layers which consist of stromatolitic bioherms and anhydrite-carbonate conglomerates and breccias within the swell top. Stromatolitic limestones are partly dolomitised and contain petroleum reservoirs of the fractured-cavern type. Fissures and cavities are partly filled with halite and anhydrite. Oil deposits occur in these rocks within the Paliessie, Davydaŭka, West-Ciškaŭka and West-Dubraŭka structures (Fig. 2). Deeper-water lithofacies are found on the swell flanks. These are thinly layered and dark clayey anhydrites interstratified with clayey limestone and dolomite.

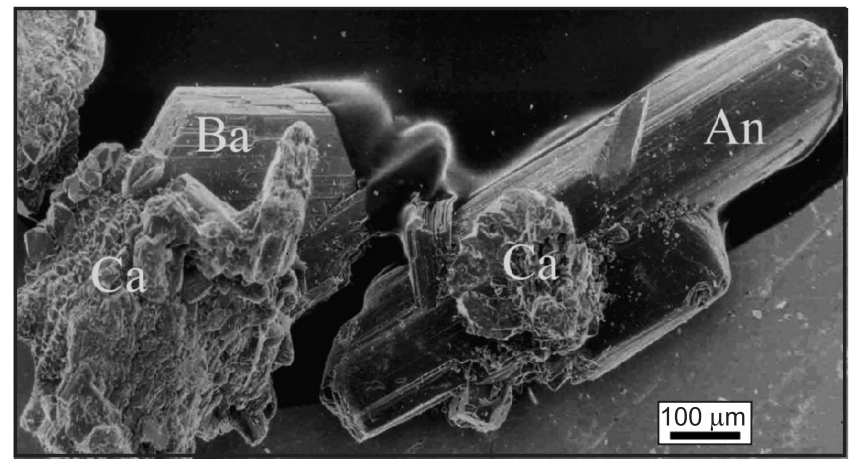

Fig. 6. Anhydrite (An), barite (Ba) and carbonate (Ca) from the water-insoluble residue of rock salt from the Lower Saliferous Formation of the Prypiać Trough; Biarezina 10 borehole (depth $1503 \mathrm{~m})$

Electron microscope photo 
Two varieties of sulphate rock are of special interest due to their lithological peculiarities and debatable genesis. These are (1) anhydrite with a spotted texture and (2) massive anhydrite with halite inclusions which resemble filled caverns.

The first variety contains fragments and clots of carbonate material and is particularly typical of the Baryčaŭ beds at the bottom of the Halite Subformation described above. Obrovets (in Garetskiy et al., 1982) considered these rocks as a product of metasomatic replacement of carbonates by anhydrite. This seems unlikely because the solubility of anhydrite in evaporite brines is significantly higher than is that of calcite and dolomite.

The second variety of sulphate rock is interesting because the formation of caverns in the anhydrite, and their further filling with halite under conditions of generally deep water salt deposition and fast and continuous deepening of the basin bottom typical of Lebedyan time, is impossible. The genesis of such halite-anhydrite rocks we interpret in the following manner (cf. Makhnach, 2007). Anhydrite and halite precipitated together on the bottom at the salt sedimentation stage in the form of the brine-saturated mud. Then, the mud compressed, became more or less dehydrated and its components were redistributed diagenetically.

Anhydrite is a member of the accessory mineral association of rock salt. We have studied more than 100 samples and shown that anhydrite prevails over other accessory minerals, amounting to $0.02-5.7 \%$ of the total salt mass. The accompanying minerals are quartz, carbonates, barite, more rarely sulphides and fluorite. The accessory anhydrite forms granular and fibrous aggregates, and lamellar and prismatic crystals which are often twinned (Fig. 7).

Potassium-Bearing Subformation. The Potassium-Bearing Subformation of the Upper Saliferous Formation of the Prypiać Trough includes the Aresa Unit and the lower part of the Strešyn Unit (Table 1). Sulphate and sulphate-bearing rocks are moderately widespread in the Potassium-Bearing Subformation. But they are not so typical there as in the Halite Subformation. The sulphate material comprises anhydrite only.

Sulphate-bearing rocks are present predominantly in the west and north of the trough where clay-sulphate and carbonate-clay-sulphate beds are widespread (Obrovets et al., 1990). The texture of these polymineralic rocks is lenticular, flaky, nodular or spotted. Rocks with brecciated texture in which carbon-
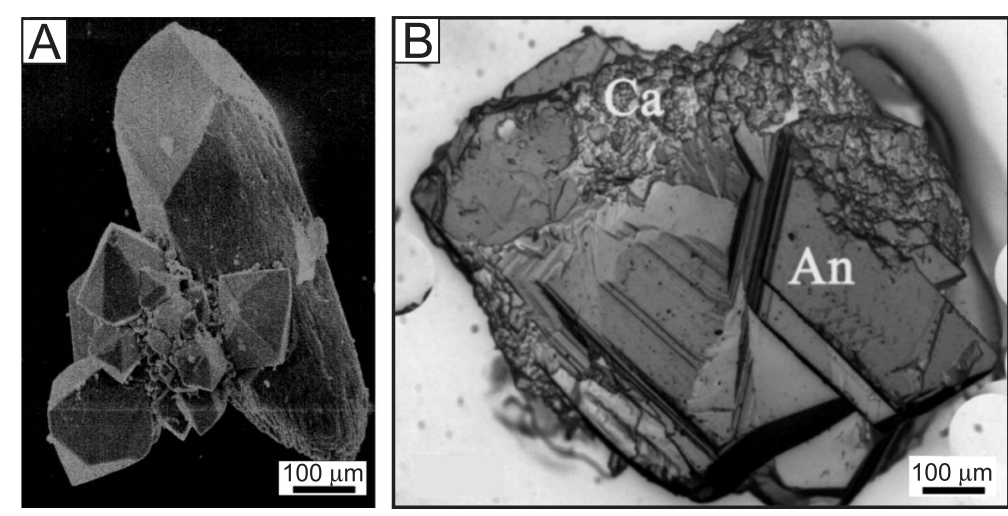

Fig. 7. Forms of accessory anhydrite occurrence in rock salt of the Halite Subformation of the Prypiać Trough (electron microscope photos)

A - crystalline aggregate of anhydrite and quartz, Aliaksandraŭka 2 borehole (depth $1550 \mathrm{~m}$ ); B - crystalline aggregate of anhydrite (An) and carbonate $(\mathrm{Ca})$, Drazdoŭka 672 borehole (depth $774 \mathrm{~m}$ ) ate-clayey fragments are cemented with anhydrite are typical. In some cases, the form of anhydrite (separate plates, nodules, lenses) and its relationships with thinly layered, clumpy and detrital limestones indicate deposition in shallow-water tidal conditions (sabkha).

The sulphate rocks proper are rather variable in composition, texture and structure (Garetskiy et al., 1982). The rocks almost always contain carbonate and clay impurities. There is a sulphate-halite rock variety in which fine-grained anhydrite is cemented with halite. The texture of sulphate rocks is similar to that of the mixed sulphate-bearing rocks described above. The anhydrite structure within lumps, lenses, nodules and beds of different thickness is micro-, fine- or medium-grained and tangled-fibrous. Varieties of coarsely crystalline anhydrite form sheaf-like, fan-shaped, spherulite and radial aggregates. Clay-carbonate lumps are threaded and fringed with needle-shaped and lamellar anhydrite crystals.

Anhydrite of the habit described above is present in the other non-salt rocks of the Potassium-Bearing Subformation, for example in carbonate, carbonate-clayey and clayey (halopelites) rocks. It forms thin lenticular aggregates and inclusions as well as chains consisting of individual grains oriented along the bedding as well as disordered scattered grains.

Anhydrite as a separate mineral or, more frequently together with carbonate-clayey material, forms thin layers tracing basal (non-salt) parts of seasonal, annual and more long-term rhythms of evaporite sedimentation. Some anhydrite is usually present within rock salt, sylvinite and carnallite interlayers. In particular, micro- and fine-grained needle-shaped and prismatic crystals $(0.01-0.1 \mathrm{~mm})$ of anhydrite are located among halite grains in rock salt. These crystals form tangled-fibrous and radial aggregates locally including moderately coarse (up to $0.7 \mathrm{~mm}$ ) prismatic anhydrite crystals which frequently intergrow through halite grains. This indicates that anhydrite was a primary phase (Sedun and Eroshina, 1969).

One more variety of anhydrite is worth of note. It is found in the upper part of the Strešyn horizon which represents a leached part of the Potassium-Bearing Subformation and formally belongs to the Oversaliferous Formation (Table 1). There, anhydrite as a residual product of selective dissolution of salt-bearing rocks occurs immediately over the salt surface. This partly dissolved and redeposited mineral forms peculiar sulphate-carbonate "cakes" and thin crusts. Leaching and redeposition of sulphate material were accompanied by hydration of anhydrite and formation of fibrous gypsum-selenite in rock fissures.

\section{FACIES ANALOGUE OF THE UPPER SALIFEROUS FORMATION}

Anhydrite occurs in the Upper Famennian (the Lebedyan and Aresa units) sulphate-carbonate-clayey deposits within the western part of the Prypiać Trough. There, these deposits are facies analogue of the Halite Subformation and of the lower part of the Potassium-Bearing Subformation. Anhydrite is found in the lower part of gypsum-bearing rock strata which contain three gypsum and one gypsum-anhydrite horizon forming the Brynioŭ gypsum deposit (Fig. 2).

According to the results of core study, anhydrite is present in the lower layer of the lowest productive horizon (IV) only. This layer is composed of a gypsum-anhydrite rock and characterized by a zonal constitution. The middle part is made of pearl-grey 
anhydrite with rosettes of grey-beige spar gypsum (Fig. 8A) which are discrete or interconnected with thin veins of saccharoidal gypsum or selenite (a fibrous variety of gypsum). The upper and lower parts of the layer do not contain anhydrite and are totally made of gypsum.

Anhydrite of gypsum-anhydrite rocks is of massive texture and aphanitic macrostructure. Thin section study shows that the anhydrite microstructure is xenomorphic, fine- and microlepidoblastic with parallel or tangled orientation of scales. The boundaries between lepidoblastic anhydrite and granoblastic gypsum aggregates are blurred (Fig. 8B).

Mineralogical analysis data show that some anhydrite also occurs in overlying gypsum units (II and III).

Petrographic, sulphur isotope and strontium content investigations of gypsum and anhydrite as well as data on the chlorine and sodium content in water extracted from these minerals (Makhnach et al., 2003a, b) point to the metasomatic nature of anhydrite replacement by gypsum. The characteristics of this process will be briefly described below in the section on the Brynioŭ gypsum deposit.

\section{LOWER PERMIAN}

Anhydrite occurs in the evaporite lithofacies of the Asselian and Sakmarian of Belarus (Table 2).

Interlayers and clusters of this mineral are found in the Prudok Suite strata (Asselian) within the Prypiać Trough and Brahin-Loeŭ Saddle (Fig. 2; Golubtsov and Makhnach, 1961; Makhnach et al., 2001). The suite is subdivided into the lower (sulphate-lacking) and upper (sulphate-bearing) subsuites. The upper one consists of speckled clays with interlayers of marl, dolomite, anhydrite, gypsum and sandstone with an anhydrite-clayey cement. Clusters of anhydrite and gypsum occur in all the rocks mentioned above. The quantity and thickness $(0.2-1.0 \mathrm{~m})$ of pearl-grey anhydrite interlayers in the sulphate-bearing subsuite of the trough increase in a south-east direction towards the
Brahin-Loeŭ Saddle. The subsuite consists of five rhythmic units. Anhydrite interlayers are present in the upper two of these. The lower rhythmic units contain only clusters of anhydrite within terrigenous and terrigenous-carbonate rocks.

Interlayers, clusters and accessory admixtures of anhydrite are observed in the Svaboda Suite of the Prypiać Trough which represents the Sakmarian saliferous rock strata (Vysotskiy and Kruchek, 2000; Vysotskiy et al., 2004). The deposits are restricted to the central part of the trough (the SastovičySkalodzin tectonic step; Fig. 2). The Svaboda Suite is composed of rock salt with beds and interlayers of red clayey siltstone and sandstone as well as with a potassium-bearing unit at the bottom. This unit contains potassium and magnesium chlorides and sulphates, halite and sporadic aggregates of anhydrite (Vysotskiy et al., 1988). Anhydrite beds (up to $3 \mathrm{~m}$ in thickness) occurring within red terrigenous strata are also found in the South-Damanavičy structure (Fig. 2). The rocks are pearl-grey, compact, massive, without admixture of carbonate and clay material. These anhydrite types are the facial analogue of salt of the lower part of the salt-bearing sequence (Kislik et al., 1985).

\section{GYPSUM}

\section{MIDDLE DEVONIAN}

Gypsum is widespread in the Middle Devonian strata of Belarus (Makhnach et al., 2001). It occurs in the lower (carbonate-sulphate) geological unit of the Asvieja Unit (Eifelian) in the Orša Depression, Žlobin and Latvijas saddles and partly in the Belarusian Anteclise (Table 1 and Fig. 1). This unit is 14-20-m-thick. Sulphate rocks are replaced with clay-carbonate breccia within the eastern slopes of the Belarusian Anteclise. Anhydrite takes the place of gypsum in the Asvieja Unit of the Prypiać Trough.
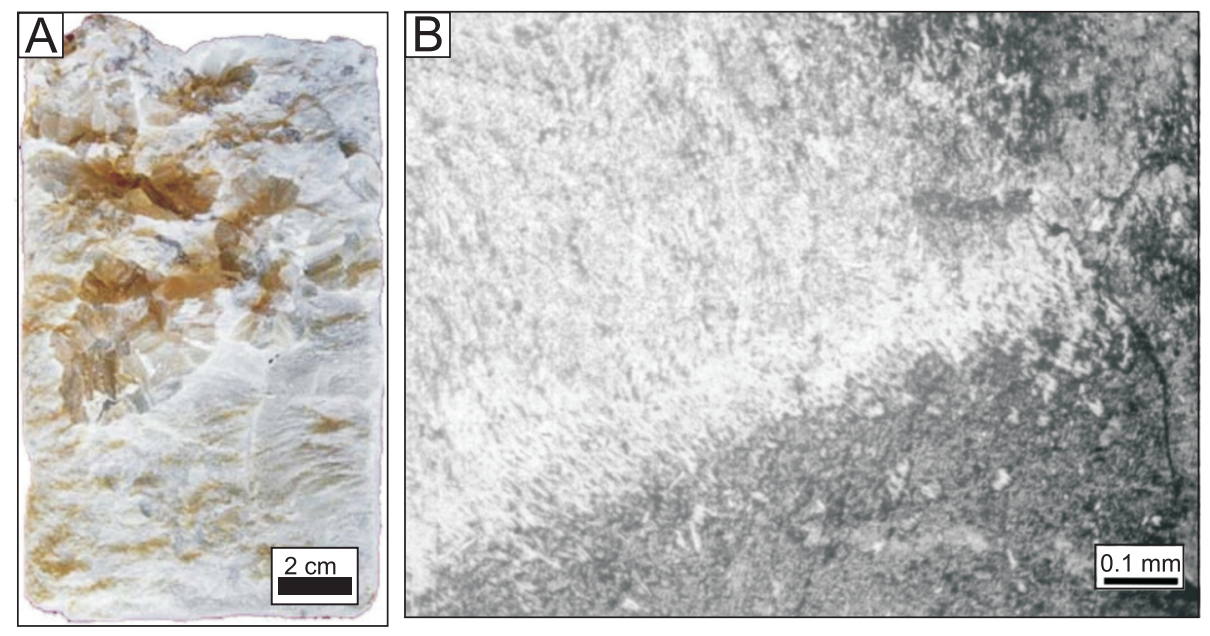

Fig. 8. Anhydrite and gypsum interrelations in the Lebedyan-Aresa strata of the Brynioŭ gypsum deposit

A - macrocrystalline gypsum rosettes (brown) in massive aphanitic anhydrite, borehole 2 (depth 581-582 m) core photograph (by T.E. Kolosova); B - blurred boundary between anhydrite with microlepidoblastic structure (dark) and gypsum with coarse-grained, xenomorphic, granoblastic structure (light), borehole 41 (depth $327 \mathrm{~m}$ ) cross-polarized photomicrograph 
Gypsum of the Asvieja Unit is characterized by the following lithological and mineralogical features. It usually occurs in rather thin interlayers in carbonate-clayey deposits. These interlayers are frequently deformed and contain horizontal, inclined and vertical cracks filled with gypsum (Fig. 9A). The carbonate-clayey host rock which contains gypsum interlayers is often brecciated and includes gypsum veins. The structure of the gypsum is lamellar (Fig. 9B) or fibrous, more rarely granular. Combinations of different structures may be found in one core sample. The gypsum is pink, yellow, orange or grey.

These characteristics of gypsum occurrence and structure suggest that it is a product of primary anhydrite alteration which took place not far from the surface. Gypsum lies not very deep (60 to $200 \mathrm{~m}$ ) even now whereas there were many long breaks of deposition after the Asvieja Unit formation in North and Central Belarus when transformation of anhydrite to gypsum might have taken place. This transformation was accompanied by the "gypsum tectonics" process shown by the brecciation occurring within the intervals containing gypsum.

The strontium content of the gypsum also indicates its secondary origin (by replacement of anhydrite). This content is as low as $150 \mathrm{ppm}$ on average, or $190 \mathrm{ppm}$ after recalculation to waterless calcium sulphate (Makhnach, 1999). The strontium content in anhydrite of the Asvieja Unit in the Prypiać Trough is much higher (750-2200 ppm). Earlier, Makhnach (1989), following Boyko (1973), showed that there is no reason to consider the degree of strontium capture by anhydrite and gypsum different though, the crystal lattice of anhydrite is rhombic while the gypsum lattice is monoclinic. Therefore, there is another reason for the significantly different strontium content of anhydrite within the Prypiać Trough and in contemporaneous gypsum outside the trough. As the Prypiać Trough had not yet formed in the Eifelian, there is no reason to suppose that strontium content in sea water of the evenly shallow epicontinental sea of Belarus fluctuated considerably from one part of the depositional basin to another. Thus, it is logical to explain the extremely low strontium content in gypsum of the Asvieja Unit in the following manner: gypsum is a product of the simultaneous dissolution of anhydrite and crystallisation of gypsum in its place (metasomatic replacement; Makhnach, 1999). Such replacement led to decreasing strontium content in the newly-formed phase because the partition coefficient between solid calcium sulphate and solution is less than one (Kushnir, 1980). In addition, the frequently observed coarse-plate structure of gypsum indicates that the mineral was repeatedly recrystallised in weakly mineralised underground water. This led to formation of increasingly strontium-depleted gypsum.

\section{UPPER DEVONIAN}

Frasnian. Gypsum of depositional origin was found in the Frasnian strata of the North-Prypiać Shoulder (Fig. 2) in the course of diatreme prospecting (Kruchek et al., 1999; Obukhovskaya et al., 2005, 2007). The Černin Unit, composed of clays and marls with gypsum, dolomite and sandstone interlayers was found there at the depth interval of $278.6-354.0 \mathrm{~m}$.

The texture of the gypsum is massive, rosette-like, in places brecciated and nodular (Fig. 10), the structure being needle-shaped and coarse-crystalline. Microporphyritic carbonate inclusions are present within the gypsum rock matrix.

$$
\begin{gathered}
\text { FACIES ANALOGUE } \\
\text { OF THE UPPER SALIFEROUS FORMATION }
\end{gathered}
$$

As previously mentioned, the Brynioŭ gypsum deposit was revealed in the western part of the Prypiać Trough (Fig. 2). The deposit comprises the Lebedyan and Aresa strata of the Upper Famennian which are the facies analogue of the Upper Saliferous Formation.

The depth of the top of gypsum-bearing strata within the deposit changes from 142.8 to $460.3 \mathrm{~m}$, and the thickness from 37.2 to $252.7 \mathrm{~m}$. The beds of gypsum, mixed carbonate-sulphate rocks, marl, calcareous and dolomite clays, limestone, dolomite and more rarely sandstone and siltstone alternate in the gypsum-bearing rock mass. Four gypsum units numbered from the top I to IV are distinguished in the deposit. The two
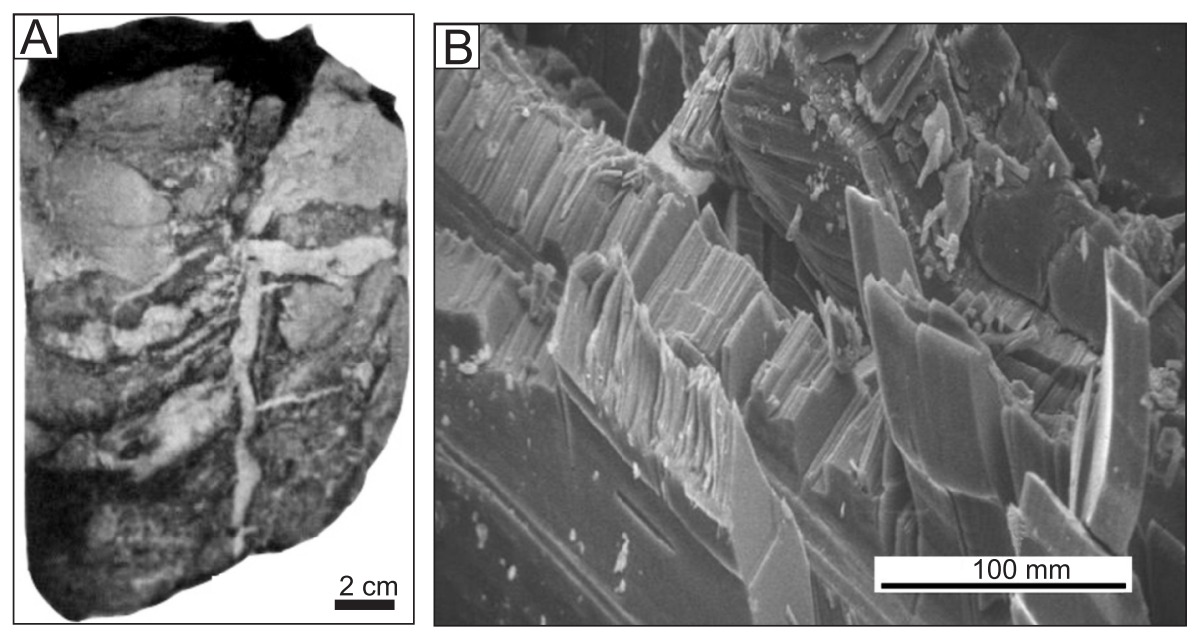

Fig. 9. Gypsum in the Asvieja Unit of Belarus

A - brecciated rock consisting of gypsum (light) and calcareous clay, northern slope of the Belarusian Anteclise, Liepiel 8 borehole (depth 250-255 m), core photograph; B - gypsum under SEM, the central part of the Orša Depression, Talačyn 38 borehole (depth 295-299 m) 


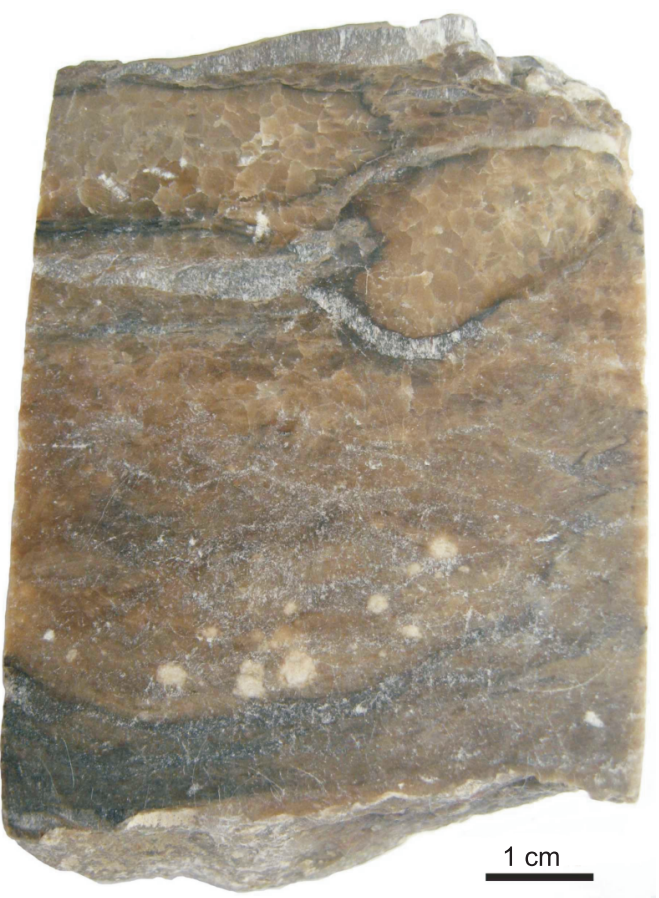

Fig. 10. Nodular texture of gypsum in the Černin Unit of the North-Prypiać Shoulder

Uvaravičy 26 borehole (depth $350 \mathrm{~m}$ ) core photograph (sample from the collection of S.A. Kruchek)

lower units (III and IV) are of economic interest. One or several gypsum beds and vein bodies are present in each unit (Makhnach et al., 2003a, b).

Gypsum beds are typical of all four units. The rocks show massive texture or spotted and banded distribution of several varieties of gypsum (spar, saccharoidal and alabaster). Selenite in the form of concordant veins and lenses is found within the gypsum beds. The rocks are grey, white, pink or beige.

Gypsum-anhydrite rocks occur in the middle part of the lower bed of the unit IV. There, gypsum rosettes $(1-2 \mathrm{~cm})$ and clusters are scattered within an anhydrite mass (Fig. 8A). Locally, the rosettes are interconnected by gypsum veins. Mixed gypsum-anhydrite rocks progressively give way to gypsumbearing ones due to the growth of gypsum rosettes and saccharoidal gypsum forming near the top and the bottom of the bed.

Vein bodies of small thickness usually consist of one structural variety (selenite or saccharoidal gypsum). Thicker bodies often have a zonal fabric, with central parts of saccharoidal gypsum and marginal parts of selenite.

Gypsum rocks contain some admixture of carbonate, clay and siliceous material. The carbonate material includes scattered calcareous micrite and finely crystalline calcite aggregates. Some samples contain minor amounts of chalcedony spherulites, sulphides, celestine, barite and fluorite.

Carbonate-sulphate and clay-carbonate-sulphate rocks with varying amounts of carbonate and clay material are found as intraformational and interstratal interlayers and characterized by a mineral association similar to that of gypsum rocks.

The rocks are frequently brecciated. Carbonate fragments of breccia are cemented with gypsum. Relics of depositional bedding, frequently subvertical in the core, are seen in some sections (Fig. 11). Brecciated carbonate rocks with gypsum may be a result of "gypsum tectonics", that is of rock volume increase in anhydrite to gypsum transformation.

There are four morphostructural varieties of gypsum within the Brynioŭ gypsum deposit.

Spar gypsum typical of beds and almost lacking in vein bodies comprises xenomorphic or hypidiomorphic, predominantly even-grained aggregates of coarse (more than $4 \mathrm{~mm}$ across) isometric or thick-lamellar crystals probably formed as a result of anhydrite replacement (Fig. 12A). Such microstructure may be defined as xenomorphic or hypidiomorphic, homeoblastic, coarsely crystalline. Aggregates of this microstructure are found in almost all sulphate-containing rocks; they dominate in gypsum-anhydrite rocks where the only spar variety of gypsum is present among the aphanitic anhydrite mass.

The saccharoidal gypsum variety is composed of evengrained aggregates consisting of fine or medium-size hypidiomorphic or panidiomorphic lamellar crystals (hyp- or panidiomorphic, homeoblastic, lamellar, fine to medium-crystalline microstructure; Fig. 12B). Saccharoidal gypsum prevails in gypsum and carbonate-gypsum rocks where it is probably a product of anhydrite replacement. Such gypsum is poorly developed in gypsum-anhydrite rocks; there, it forms thin sinuous veins and small clusters within the anhydrite mass and among homeoblastic, coarsely crystalline aggregates.

The alabaster variety of gypsum in the form of small spots occurs in sulphate rocks among spar aggregates. It is composed of fine-grained clusters of isometric or slightly elongated crystals distributed mosaically or parallel to each other in the form of bunches (hypidiomorphic, homeoblastic, fine-grained, mosaic or bunch-shaped microstructure) (Fig. 12C). Alabastrine gypsum occurs predominantly in the lower beds (III and IV) indicating that this gypsum variety is of relict origin and is consistent with the initial stage of anhydrite hydration.

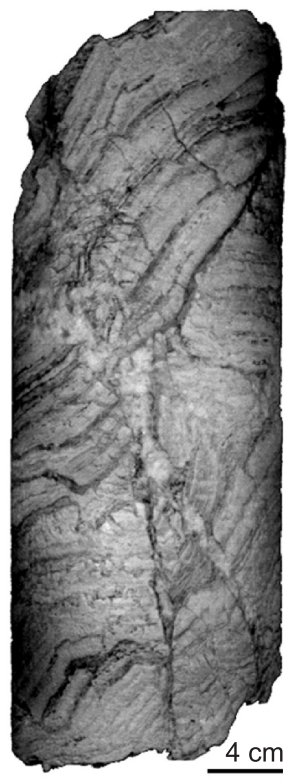

Fig. 11. Brecciated marl with fissures filled by secondary gypsum in the Lebedyan-Aresa strata of the Brynioŭ gypsum deposit

Borehole 8 (depth 604-607 m), core photograph 

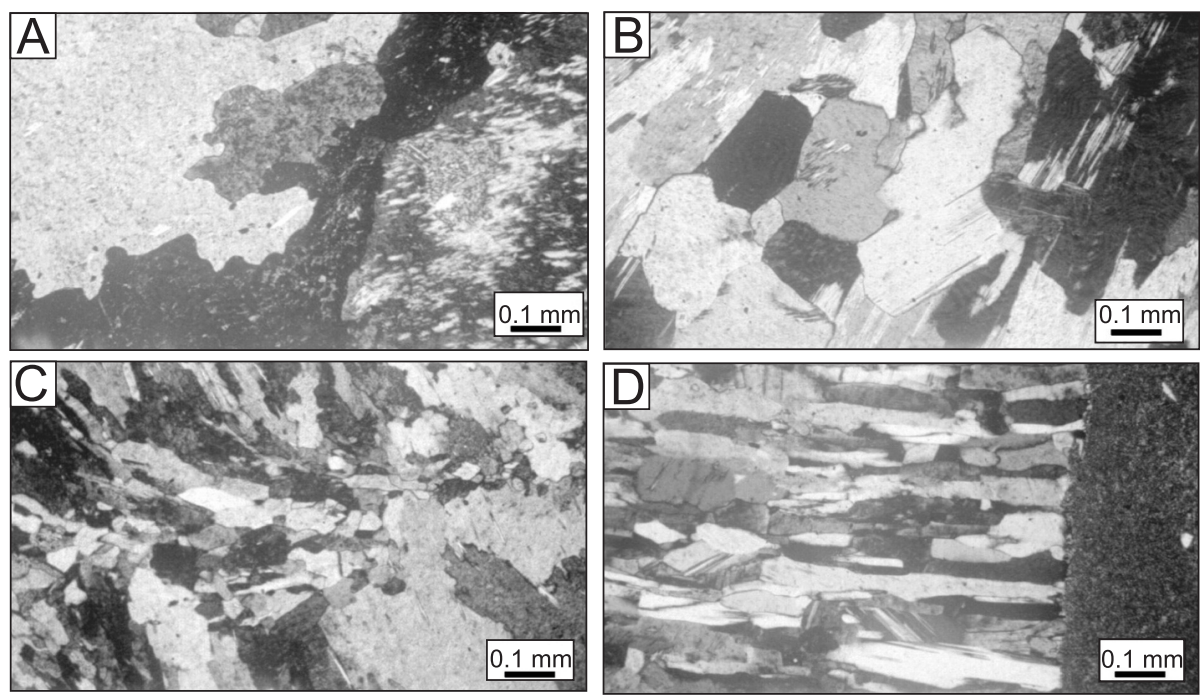

Fig. 12. Microstructure of different gypsum varieties within the Brynioŭ deposit; borehole 15 (cross-polarized photomicrograph)

A - spar gypsum, coarsely-crystalline, homeoblastic microstructure (depth $314 \mathrm{~m}$ ); B - saccharoidal gypsum, medium-crystalline, hypidiomorphic, homeoblastic, prismatic microstructure (depth $246 \mathrm{~m}$ ); C - alabaster gypsum, spotted distribution of aggregates with fine-medium-crystalline, hypidiomorphic, prismatic and finely-crystalline, xenomorphic, prismatic, bunch-shaped microstructure (depth $246 \mathrm{~m}$ ); D - gypsum-selenite at the contact with pelitomorphic carbonate rock, fine-medium-crystalline, hypidiomorphic, palisade microstructure (depth $350 \mathrm{~m}$ )

The selenitic variety of gypsum is widespread in productive units of the deposit. Thin subvertical and subhorizontal veins in beds and interlayers as well as peripheral zones of thick veins, the central parts of which consist of saccharoidal gypsum, are entirely composed of selenite. This gypsum variety is represented by clusters of elongated crystals of different size and shape which are parallel to each other and perpendicular to the vein borders. The shape of selenite crystals resembles short and long bars and needles. The microstructure of this gypsum variety may be defined as anisomerous and even-grained, panidiomorphic, needle-shaped and hypidiomorphic, palisade (Fig. 12D).

Gypsum and gypsum-anhydrite rocks of the productive units within the Brynioŭ gypsum deposit were formed in the following manner.

Initially, the deposit area represented an uplifted area inside the evaporite basin. Accumulation of sulphate strata coeval to salt deposition took place on this uplift. Probably, calcium sulphate precipitated in the form of gypsum which was rather rapidly transformed to anhydrite as a result of sediment burial (Sonnenfeld, 1984). Then, uplift led to relocation of anhydrite upwards into the zone of hypergenesis and its transformation to gypsum. The replacement process was metasomatic: dissolution of anhydrite and crystallisation of gypsum in its place were practically simultaneous. It is possible to suggest a temporal succession of gypsum structural varieties forming in bedded bodies:

- nucleation and growth of singular gypsum crystals by metasomatic replacement of anhydrite;
- formation of fine-grained alabaster and/or rosette-shaped spar aggregates;

- enlargement of gypsum spots and massive spar gypsum forming;

- total replacement of anhydrite by saccharoidal gypsum.

Formation of differently oriented selenite veins on the bases of fissures could have taken place many times, beginning from the early stage of gypsum formation and was attended by the subsequent filling of open hollows by aggregates of saccharoidal gypsum.

\section{OVERSALIFEROUS FORMATION}

Gypsum in the Oversaliferous Formation (Famennian) of the Prypiać Trough occurs in the gypsum-bearing part of the formation which corresponds to the upper half of the Strešyn Unit (Table 1). Gypsum-bearing rocks of this unit are a residual product of the underground post-depositional dissolution of the upper part of the Upper Saliferous Formation (Khodkov et al., 1967; Lupinovich et al., 1968). The thickness of gypsum-bearing deposits is from 50 to $700 \mathrm{~m}$. These are composed of calcareous clay, marl, more rarely limestone and sandstone with numerous beds, interlayers and veins of gypsum.

The formation of gypsum took place in a brine environment caused by rock salt and potassium salt leaching. Gypsum formed as a result of anhydrite hydration (beds with granular structure, mixed gypsum-anhydrite-limestone-clay rocks) and filled fissures in marls, clays and limestones as well as formed cement in sandstones. 
White and pinky-orange vertical, inclined and horizontal gypsum veins (from several millimetre to several centimetre wide), which cut clays and marls, are widespread. These veins formed on the bases of fissures after lithification. Usually, they are characterized by fibrous texture and orientation of elongated crystals perpendicular to the vein walls (Fig. 13A). The gypsum cement of sandstone beds within the clay-marl oversaliferous deposits is poikilitic, mainly porous. Its secondary origin is inferred from the existence of idiomorphic overgrowths on detrital quartz and feldspar grains sealed by gypsum (Fig. 13B).

The genetic relation of the secondary gypsum formation with the process of underground salt leaching is indicated as follows.

As noticed earlier (Khodkov et al., 1967; Lupinovich et al., 1968), the presence of hematite fringes at the selvages of fissures filled with gypsum as well as the colouring of gypsum itself by hematite are often observed. The iron content in such reddish gypsum is one order higher (up to $3300 \mathrm{ppm}$ ) than the average $\mathrm{Fe}$ content in oversaliferous gypsum as a whole (Makhnach, 1989). This suggests that finely dispersed hematite released during potassium salt dissolution was captured by filtration flow and redeposited mechanically in fissures together with crystallising gypsum.

It cannot be ruled out that crystallisation of gypsum was locally associated with the opening of closed fissures, the walls of which were contaminated with the iron oxide. Primarily, these correspond to salt streaks and water-break fissures filled with red salt within halopelite beds of the upper units of the Upper Saliferous Formation, transferred later to the lower part of the Oversaliferous Formation. Then, the top and the bottom of the streaks and fissure walls were interlocked as a result of salt dissolution. Thus, these streaks and fissures were transformed into numerous seams traced by the residual products of salt leaching, i.e. iron oxides (Khodkov, 1964). Many of these seams become open once again under the force of gypsum crystallisation. The scheme described helps to explain the dominance of gypsum aggregates of fibrous texture with elongated crystals oriented perpendicular to the vein walls in oversaliferous deposits (Fig. 13A). Crystals of such shape and ori- entation result from simultaneous processes of their growth and cavity formation.

The genetic relation of gypsum formation with evaporite dissolution in the Strešyn Unit is supported by gypsum fillings of pseudocubic voids formed as a result of halite crystal dissolution.

\section{LOWER PERMIAN}

Gypsum interlayers and clusters occur in the upper (sulphate-bearing) subsuite of the Prudok Suite (Asselian) in the central part of the Prypiać Trough (Table 2). These are present within speckled clays, sandstones, marls and dolomites (Golubtsov and Makhnach, 1961).

Gypsum is also found in deposits which are non-salt analogue of the saliferous deposits of the Svaboda Suite (Sakmarian) in the South Damanavičy structure of the trough (Fig. 2). There, a clay-anhydrite rock unit located at the depth interval of 620-648 m includes interlayers and veins of white and smokecoloured gypsum among rhythmically alternating brown clay, grey anhydrite, pinky-grey sandstone and reddish-brown conglomerate (Makhnach et al., 2001).

\section{CONCLUSIONS}

Anhydrite is widespread in the Prypiać Trough in the form of beds and clusters in the Subsaliferous Terrigenous and Carbonate formations (Eifelian and Frasnian), the Lower Saliferous Formation (Frasnian), the Intersaliferous and Upper Saliferous formations (Famennian). It is also present in the Asselian and Sakmarian deposits of the trough.

Gypsum is widely distributed in North and Central Belarus, where it occurs in Eifelian deposits. It is also found in the Frasnian deposits of the North-Prypiać Shoulder. As a component of facies analogue of the Upper Saliferous Formation, gypsum forms the Brynioŭ deposit in the west of the Prypiać Trough. Also this mineral is observed in the Oversaliferous For-
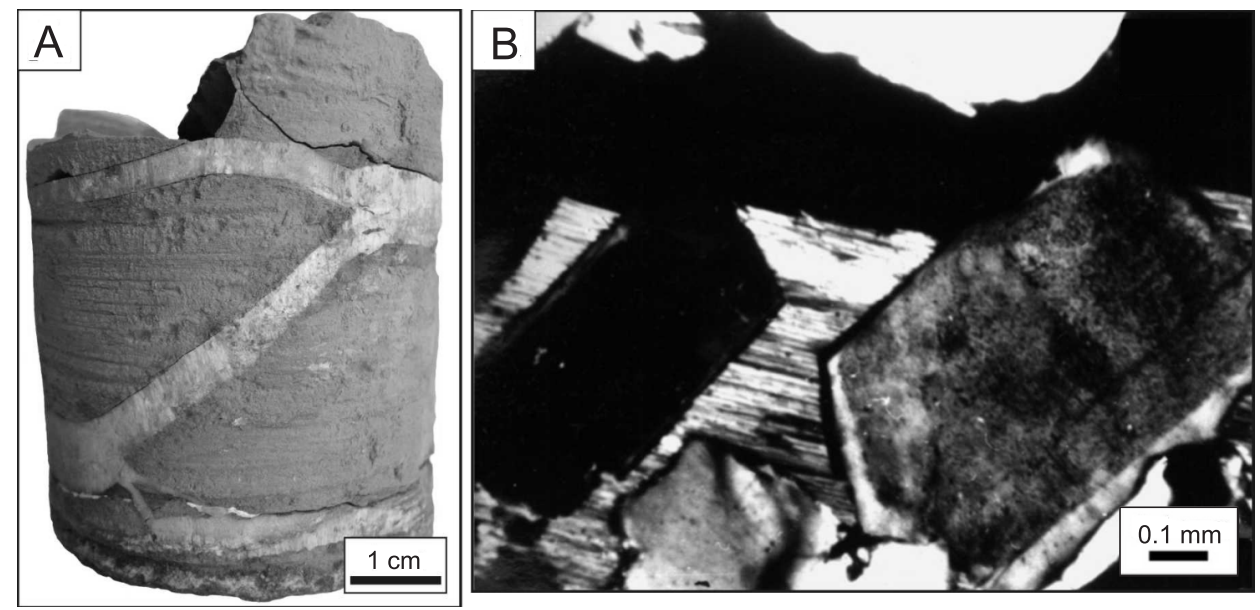

Fig. 13. Gypsum of the Oversaliferous Formation of the Prypiać Trough

A - veins in dolomite clay composed of elongated gypsum crystals oriented perpendicular to the vein walls, the Starobin deposit of potassic salt, Listapadavičy 87 borehole (depth 305-307 m), core photograph; B - regeneration overgrowths on feldspar grains sealed with gypsum cement, the Turaŭ centriclinal depression, borehole 505 (depth 704-719 m), cross-polarized photomicrograph 
mation (Famennian) and in the Asselian and Sakmarian strata of the trough.

Our review shows that some of the described mineral objects are poorly studied in comparison with other ones. Particularly, this concerns the Eifelian anhydrite and gypsum, the anhydrite beds in the Intersaliferous Formation and in the Frasnian part of the Subsaliferous Formation as well as the Permian sulphate rocks. We connect perspectives of the fur- ther investigation of sulphate minerals of Belarus with the development of a new generation of geological surveying within its territory.

Acknowledgements. The authors thank Prof. T.M. Peryt, Dr. S. Hryniv, Dr. J. Hammer and Prof. V.N. Kuleshov for useful comments that have improved the paper.

\section{REFERENCES}

Boyko, T.F., 1973. Redkiye elementy $v$ galogennykh formatsiyakh (in Russian). Nauka, Moskva.

Garetskiy, R.G., Kislik, V.Z., Vysotskiy, E.A., Eroshina, D.M., Petrova, N.S., Obrovets, S.M., Sedun, E.V., Protasevich, B.R., 1982. Devonskiye solenosnye formatsii Pripyatskogo progiba (in Russian). Nauka i Tekhnika, Minsk.

Golubtsov, V.K., Makhnach, A.S., 1961. Fatsii territorii Belorussii v paleozoye i rannem mezozoye (in Russian). Izd. AN BSSR, Minsk.

Khodkov, A.E., 1964. Rol protsessov podzemnogo vyschelachivaniya $v$ geologii Starobinskogo mestorozhdeniya (in Russian). Trudy VNIIG, 46: 26-46.

Khodkov, A.E., Valukonis, G.J., Korennov, J.F., 1967. Utochneniye geneticheskoy prirody glinisto-mergelistoy tolschi Starobinskogo mestorozhdeniya (in Russian). Trudy VNIIG, 53: $36-46$.

Kislik, V.Z., Vysotskiy, E.A., Golubtsov, V.K., Karpov, V.A., Akulich, V.G., Kusov, B.R., Koldashenko, T.V., 1985. Permskiye kalienosnye otlozheniya Pripyatskogo progiba i ikh kalienosnost (in Russian). In: Geologicheskoye stroyenie i razvitie territorii Belorussii (eds. V.A. Kovalev, V.K. Golubtsov and A.M. Sinichka): 142-149. BelNIGRI, Minsk.

Kruchek, S.A., 1979. O stratigraficheskoy skheme mezhsolevykh otlozheniy verkhnego devona Pripyatskoy vpadiny (in Russian). In: Geologicheskoye izucheniye territorii Belorussii (eds. R.G. Garetskiy, V.A. Kuznetsov and A.V. Kudelskiy): 5-15. Institut Geokhimii i Geofiziki AN BSSR, Minsk.

Kruchek, S.A., Obukhovskaya, T.G., Levyy, M.G., Obukhovskaya, V.Y., 1999. Stratigrafiya devonskikh otlozheniy Uvarovichsko-Uritskoy ploschadi (yugo-vostok Belarusi) (in Russian). In: Problemy almazonosnosti Belarusi (ed. G.I. Emelianov): 57-71. BeINIGRI, Minsk.

Kruchek, S.A., Matveev, A.V., Yakubovskaya, T.V., Naidenkov, I.V., Veretennikov, N.V., Obukhovskaya, T.G., Sanko, A.F., Plax, D.P., eds., 2010. Stratigraficheskiye skhemy dokembriyskikh i fanerozoyskikh otlozheniy Belarusi: obyasnitelnaya zapiska (in Russian). "BelNIGRI". Minsk.

Kurochka, V.P., 1968. Atlas mikrotekstur i struktur porod devonskogo osadochnogo kompleksa Pripyatskogo progiba (in Russian). Nauka i Tekhnika, Minsk.

Kushnir, J., 1980. The coprecipitation of strontium, magnesium, sodium, potassium and chloride ions with gypsum: an experimental study. Geochimica et Cosmochimica Acta, 44: 1471-1482.

Lupinovich, J.I., Kislik, V.Z., Zelentsov, I.I., Vishnevskiy, V.N., 1968. Proiskhozhdeniye gematitovykh prosloyev $v$ nadsolevykh tolschakh kaliynykh mestorozhdeniy (in Russian). Litologiya i poleznye iskopaemye, (6): 86-97.

Makhnach, A.A., 1989. Katagenez i podzemnye vody (in Russian). Nauka i Tekhnika, Minsk.
Makhnach, A.A., 1999. Geokhimicheskaya otsenka mekhanizma prevrascheniya angidrita $v$ gips (in Russian). Doklady NAN Belarusi, 43: 90-93.

Makhnach, A.A., ed., 2007. Postsedimentatsionnye izmeneniya otlozheniy platformennogo chekhla Belarusi (in Russian). Belorusskaya Nauka, Minsk.

Makhnach, A., Mikhaylov, N., Kolosov, I., Gulis, L., Shimanovich, V., Demeneva, O., 2000. Comparative analysis of sulfur isotope behavior in the basins with evaporites of chloride and sulfate types. Sedimentary Geology, 134: 343-360.

Makhnach, A.A., Streltsova, G.D., Gulis, L.F., Mikhaylov, N.D., 2003a. Osobennosti khimicheskogo sostava sulfatnykh porod Briniovskogo mestorozhdeniya gipsa (in Russian). Litasfera, 2: 140-146.

Makhnach, A.A., Streltsova, G.D., Gulis, L.F., Mikhaylov, N.D., 2003b. Petrografiya sulfatnykh porod Briniovskogo mestorozhdeniya gipsa (Pripyatskiy progib, Belarus) (in Russian). Litasfera, 2: 20-29.

Makhnach, A.S., Korzun, V.P., Kurochka, V.P., Laput, V.A., Uriev, I.I., Shevchenko, T.A., 1966. Litologiya i geokhimiya devonskikh otlozheniy Pripyatskogo progiba $v$ sviazi s ikh neftenosnostju (in Russian). Nauka i Tekhnika, Minsk.

Makhnach, A.S., Uriev, I.I., Anpilogov, A.P., Korzun, V.P., Kruchek, S.A., 1979. O soderzhanii glavnykh tipov porod $v$ mezhsolevykh otlozheniyakh Pripyatskoy vpadiny (in Russian). In: Geologicheskoye izucheniye territorii Belorusi (eds. R.G. Garetskiy, V.A. Kuznetsov and A.V. Kudelskiy): 115-122. Institut Geokhimii i Geofiziki AN BSSR, Minsk.

Makhnach, A.S., Garetskiy, R.G., Matveev, A.V., Anoshko, Ya.I., eds., 2001. Geologiya Belarusi (in Russian). IGN NAN Belarusi. Minsk.

Moskvich, V.A., Konischev, V.S., 1986. Organogennye postroyki verkhnefamenskoy solenosnoy formatsii Pripyatskogo progiba (in Russian). In: Novye dannye po geologii solenosnykh basseynov Sovetskogo Soyuza (eds. A.L. Yanshin and G.A. Merzliakov): 94-101. Nauka, Moskva.

Obrovets, S.M., Vysotskiy, E.A., Kislik, V.Z., 1990. Litologo-fatsiaInoye rayonirovaniye kalienosnoy subformatsii Pripyatskogo progiba (in Russian). In: Usloviya obrazovaniya mestorozhdeniy kaliynykh soley (eds. G.A. Merzliakov and M.A. Zharkov): 125-132. Nauka, Novosibirsk.

Obukhovskaya, T.G., Kruchek, S.A., Pushkin, V.I., Nekriata, N.S., Obukhovskaya, V.Y., 2005. Stratigraficheskaya skhema devonskikh otlozheniy Belarusi (in Russian). Litasfera, 1: 69-88.

Obukhovskaya, V.Y., Sachenko, T.F., Kruchek, S.A., 2007. Stratigrafiya franskikh otlozheniy vostochnoy chasti Severo-Pripyatskogo plecha i sopredelnykh struktur (in Russian). Litasfera, 1: 29-39. 
Peryt, T.M., Makhnach, A.A., Halas, A., Petrychenko, O.Y., Gulis, L.F., Abravets, S.M., 2007. Sulfur isotopes in anhydrites from the Upper Devonian Prypiac' and Dnipro-Donets Basins (Belarus and Ukraine). Carbonates and Evaporites, 22: 43-54.

Pozniakevich, Z.L., 1974. Stratigrafiya, osobennosti stroeniya i istoriya osadkonakopleniya piarnusko-narovskikh otlozheniy eifelskogo yarusa Pripyatskoy vpadiny (in Russian). In: Nekotorye voprosy stratigrafii i paleontologii paleozoyskikh i mezozoyskikh otlozheniy Belorusi (ed. V.K. Golubtsov): 8-68. BelNIGRI, Minsk.

Riley, C.M., Byrne, J.V., 1961. Genesis of primary structures in anhydrite. Journal of Sedimentary Petrology, 31: 553-559.

Sedun, E.V., Eroshina, D.M., 1969. Petrografiya osnovnykh raznovidnostej kamennoy soli Pripyatskoy vpadiny (in Russian). In: Geologiya i petrografiya kaliynykh soley Belorusii (eds. A.S. Makhnach and Y.I. Lupinovich): 204-244. Nauka i Tekhnika, Minsk.

Sonnenfeld, P., 1984. Brines and Evaporites. Academic Press, Orlando.
Uriev, I.I., Anpilogov, A.P., 1977. Podsolevoy devon Pripyatskoy vpadiny (regionalnye zakonomernosti stroeniya i sostava) (in Russian). Nauka i Tekhnika, Minsk.

Vysotskiy, E.A., Kruchek, S.A., 2000. Stratigrafiya i obstanovki nakopleniya permskikh evaporitov Pripyatskogo progiba (in Russian). In: Problemy formirovaniya i kompleksnogo osvoeniya mestorozhdeniy solej. Tezisy dokladov VI solevogo soveschaniya (ed. A.I. Kudriashov): 44-46. Gornyy Institute UrO RAN, Solikamsk.

Vysotskiy, E.A., Garetskiy, R.G., Kislik, V.Z., 1988. Kalienosnye basseyny mira (in Russian). Nauka i Tekhnika, Minsk.

Vysotskiy, E.A., Makhnach, A.A., Peryt, T.M., Kruchek, S.A., 2004. Marine and continental Lower Permian evaporites of the Prypiac' Trough (Belarus). Sedimentary Geology, 172: 211-222.

Yarzhemskiy, J.J., 1960. K petrografii Belorusskogo solianogo mestorozhdeniya (in Russian). Trudy VNIIG, 40: 307-321. 